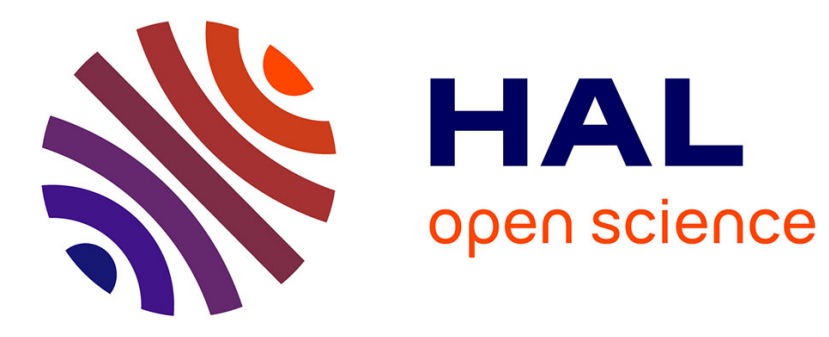

\title{
Avian feather mites (Acari: Astigmata) of Samsun, Turkey
}

\author{
A.T. Gürler, S.V. Mironov, K. Erciyes-Yavuz
}

\section{To cite this version:}

A.T. Gürler, S.V. Mironov, K. Erciyes-Yavuz. Avian feather mites (Acari: Astigmata) of Samsun, Turkey. Acarologia, 2013, 53 (1), pp.17-23. 10.1051/acarologia/20132078 . hal-01565786

\section{HAL Id: hal-01565786 \\ https://hal.science/hal-01565786}

Submitted on $20 \mathrm{Jul} 2017$

HAL is a multi-disciplinary open access archive for the deposit and dissemination of scientific research documents, whether they are published or not. The documents may come from teaching and research institutions in France or abroad, or from public or private research centers.
L'archive ouverte pluridisciplinaire HAL, est destinée au dépôt et à la diffusion de documents scientifiques de niveau recherche, publiés ou non, émanant des établissements d'enseignement et de recherche français ou étrangers, des laboratoires publics ou privés.

\section{(1) (1) $\$$}

Distributed under a Creative Commons Attribution - NonCommercial - NoDerivatives| 4.0 


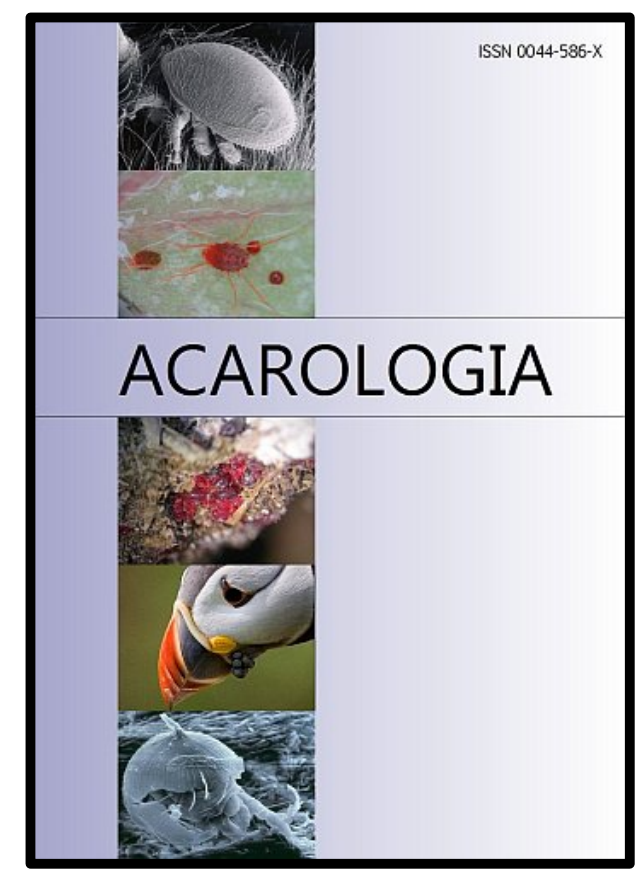

\section{ACAROLOGIA}

A quarterly journal of acarology, since 1959

Publishing on all aspects of the Acari

All information:

http://www1.montpellier.inra.fr/CBGP/acarologia/ acarologia@supagro.inra.fr

\section{OPEN ACCESS}

\section{Acarologia is proudly non-profit, with no page charges and free open access}

Please help us maintain this system by encouraging your institutes to subscribe to the print version of the journal and by sending us your high quality research on the Acari.

Subscriptions: Year 2017 (Volume 57): $380 €$ http://www1.montpellier.inra.fr/CBGP/acarologia/subscribe.php

Previous volumes (2010-2015): $250 € /$ year (4 issues)

Acarologia, CBGP, CS 30016, 34988 MONTFERRIER-sur-LEZ Cedex, France

The digitalization of Acarologia papers prior to 2000 was supported by Agropolis Fondation under the reference ID 1500-024 through the « Investissements d'avenir » programme

(Labex Agro: ANR-10-LABX-0001-01)
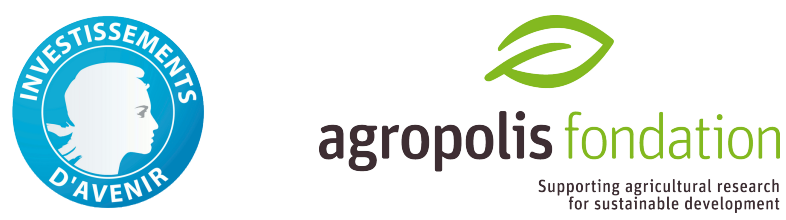

Acarologia is under free license and distributed under the terms of the

Creative Commons-BY-NC-ND which permits unrestricted non-commercial use, distribution, and reproduction in any medium, provided the original author and source are credited. 


\title{
AVIAN FEATHER MITES (ACARI: ASTIGMATA) OF SAMSUN, TURKEY
}

\author{
Ali T. GÜRLER ${ }^{1}$, Sergey V. MiRONOV ${ }^{2}$ and Kiraz ERCIYES-YAVUZ ${ }^{3}$ \\ (Received 24 August 2012; accepted 13 December 2012; published online 29 March 2013)

\footnotetext{
${ }^{1}$ Department of Parasitology, Faculty of Veterinary Medicine, Ondokuz Mayıs University, Samsun, Turkey. tgurler@omu.edu.tr 2 Zoological Institute, Russian Academy of Sciences, Universitetskaya Embankment 1, Saint Petersburg 199034, Russia. astigmata@zin.ru

3 Ornithology Research Center, Ondokuz Mayıs University, Samsun, Turkey. erciyaskiraz@yahoo.com
}

\begin{abstract}
Feather mites are one of the most important symbionts of birds, living on the feather, inside the quill, and in and on the skin. Approximately 2500 mite species from two superfamilies, Analgoidea and Pterolichoidea, have been described. Here, the feather mite fauna of 196 individuals of 42 bird species from the K1z1lirmak delta, Turkey, was investigated. We detected a total of 30 feather mite species belonging to 14 genera and 9 families: Alloptes aythinae (Alloptidae); Analges passerinus, A. spiniger, A. turdinus, Strelkoviacarus quadratus (Analgidae); Avenzoaria totani (Avenzoariidae); Freyana nyrocae (Freyanidae); Grallolichus minutus (Pterolichidae); Dolichodectes edwardsi, Joubertophyllodes modularis, Monojoubertia microphylla, Proctophyllodes cetti, P. clavatus, P. doleophyes, P. lusciniae, P. mesocaulus, P. rubeculinus, P. scolopacinus, P. sylviae, P. troncatus (Proctophyllodidae); Pteronyssoides striatus, Scutulanyssus hirundicola (Pteronyssidae); Temnalges mesalgoides (Psoroptoididae); Trouessartia inexpectata, T. jedliczkai, T. kratochvili, T. microcaudata, T. reguli, T. rubecula and T. trouessarti (Trouessartiidae). These feather mite species are all first records for Turkey. New host association records are also noted: Analges spiniger on Cettia cetti, and Dolichodectes edwardsi on C. cetti and Sylvia melanocephala.
\end{abstract}

KEYWORDS - Analgoidea; Biodiversity; Birds; Host associations; Kızılırmak delta; Pterolichoidea

\section{INTRODUCTION}

Birds harbor numerous and diverse mites (Acari) that inhabit the skin, nostrils, respiratory passages and that dwell in the plumage. Some taxonomic groups of acariens are important and dangerous parasites of wild and domestic birds feeding on blood (Ixodidae, Argasidae, Dermanyssidae). Feather mites (Acari: Astigmata) are the most numerous group of mites permanently inhabiting birds. The approximately 2500 described species are arranged into 34-38 families, occur throughout the world, and have been recorded from all avian orders (Gaud and Atyeo, 1996; Mironov and Proctor, 2008; Mironov et al., 2012, OConnor, 2009;
Proctor, 2003; Proctor and Owens, 2000). Most of these mites may be considered as commensals because they feed on the oil produced by uropygyal glands, but several families are true parasites feeding on the pith of the calamus or on epidermal tissues. Feather mites are highly specialized morphologically and ecologically to particular microhabitats on their hosts. Four main types of microhabitats occupied by feather mites are usually recognized: flight and tail feathers with firm vanes, down and contour feathers of the body, interior spaces of quills, and the skin surface. Some families are even represented by endoparasites: mites of the family Turbinoptidae inhabit nasal cavities and mites of the family Knemidocoptidae burrow under the 


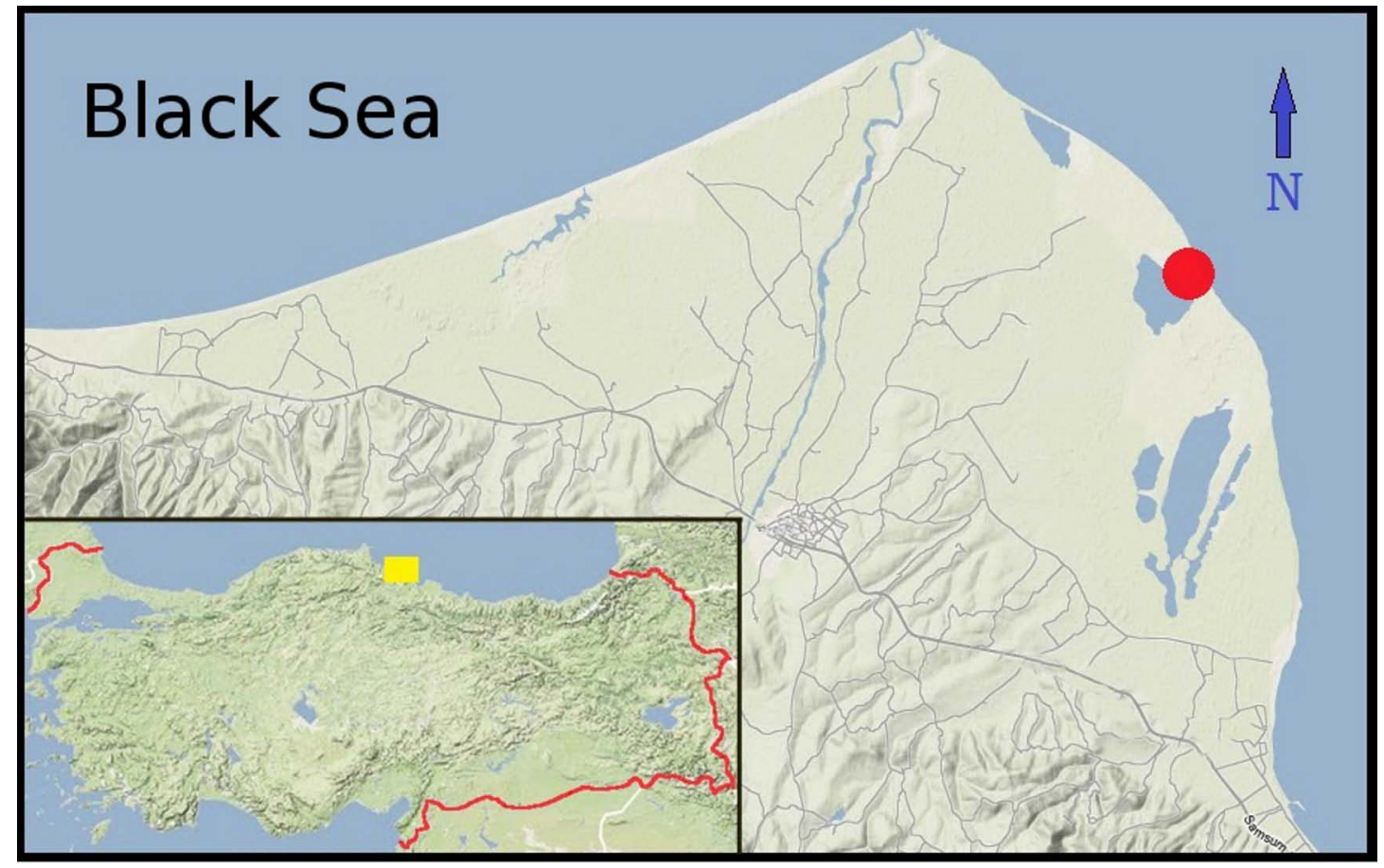

FIGURE 1: The Kizilırmak Delta, Samsun, Turkey. The red point indicates the capture site of examined birds.

skin. (Dabert and Mironov, 1999).

To date, the biodiversity of feather mites has been most thoroughly explored in Europe. Investigations have been carried out in more than 15 countries during the second half of the $20^{\text {th }}$ century (for major references see Mironov, 1996, 1997). In contrast, there are a few studies of feather mites in Turkey, and currently there is only a total of eight feather mite species recorded from this country: Ptiloxenus major (Megnin and Trouessart, 1884), Pseudolichus solutocurtus (Dubinin, 1956), and Dermoglyphus sp. from partridges (Aksın, 2010; Aksin and Erdoğmuş, 2005), Xoloptes claudicans (Robin, 1877), Periexocaulus anacanthus (Gaud and Mouchet, 1959) and Megninia ginglymura (Megnin, 1877) from quails (Aksın, 2011), Freyana anatina (Koch, 1844) from ducks (Aksın, 2007) and Chauliacia canarisi (Gaud and Atyeo, 1967) from the Alpine swift (Peterson et al., 1980).

The Kizılırmak delta is one of the biggest (560 $\mathrm{km}^{2}$ ) and best preserved wetland areas along the Black Sea coast of Turkey. Due to its various habitats ranging from beaches to flooded forests, from sand dunes to reed beds, and from mud flats to marshes, it harbors a high diversity of wildlife. The biodiversity of this area is also reflected in birds. Three hundred forty-one bird species are recorded in the Kizılırmak delta which can be observed during breeding, wintering and migration seasons. Some of these species have only been recorded in this area of Turkey and some are considered to be endangered (Barış et al., 2010). The Kızılırmak delta is an important stopover area for migratory bird species before and after they cross the Black Sea. A large number of waders and waterbirds winter in the delta. Due to these mentioned features, the delta has been selected as one of the Ramsar sites (ie, internationally recognized wetland of importance) in Turkey.

In the present paper, we report the presence of thirty feather mite species recorded during a survey of birds migrating through the Kizılırmak delta. All species are new records for the avian fauna of Turkey. 


\section{MATERIALS AND METHODS}

The study was conducted between March 2009 and May 2010 in a natural site in the Kizılirmak delta (Turkey, Samsun), which is located on the Black Sea coast at $41^{\circ} 36^{\prime} \mathrm{N}$ and $36^{\circ} 03^{\prime} \mathrm{E}$ (Figure 1). The birds were captured with mist-nets during the migration season in spring and autumn by a study group of the Ornithology Research Center (Ondokuz Mayıs University) for ringing. While ringing, 196 captured birds (Table 1) were searched visually over the entire body for the presence of feather mites living on the plumage and skin of the host. Of the 42 bird species, 24 were migratory, 14 were partially migratory (some populations are resident and some migratory) and 4 were resident (Table 1 ). In the case where mites were present on the wing feathers (primaries, secondaries and tertialis), a single feather or part of a feather bearing mites was taken off and preserved in $70 \%$ ethanol for subsequent investigation. Feather samples were brought to the laboratory and examined under a stereo microscope (Nikon SMZ 1500), and mites were mounted on slides with Hoyer's medium (Evans, 1992). Mite identifications were performed using a compound microscope (Nikon Eclipse 80i). All feather mites identified in the present study were deposited at the Faculty of Veterinary Medicine (Ondokuz Mayıs University). Latin names and systematics of birds follow Gill and Donsker (2012).

\section{RESULTS}

Selected feathers from 63 infested birds out of the 196 examined individuals (Table 1), representing 26 avian species of 16 families and 4 orders, bore various feather mite species. A total of 30 feather mite species representing 14 genera and 9 families were identified (Alloptidae, Analgidae, Avenzoiriidae, Freyanidae, Proctophyllodidae, Psoroptoididae, Pterolichidae, Pteronyssidae and Trouessartiidae). Recorded feather mite species, their host species in the investigated area, and their prevalence on each host species is shown in Table 2. All listed feather mite species are first records for Turkey.

\section{DISCUSSION}

Most examined host species in the present study are passerines, therefore the discussion of recorded fauna is focused here on mites associated with this group of birds. Feather mites collected from 21 of 30 examined passerine species (Table 1) belong to four families, Analgidae, Proctophyllodidae, Psoroptoididae and Trouessartiidae. The families Proctophyllodidae and Trouessartiidae are predominately associated with passerines, while members of the families Analgidae and Psoroptoididae are known from various orders of birds (Gaud and Atyeo, 1996; Proctor, 2003).

The family Analgidae is represented by three species of the genus Analges Nitzsch, 1818 (Analginae) and one species of the genus Strelkoviacarus Dubinin, 1953 (Anomalginae). The former genus is specific to passerines and its species are usually oligoxenous (Mironov, 1985), meaning that they are associated with several host species of one genus or of a few closely related genera. Analges spiniger was found on three hosts of the family Sylviidae: Sylvia atricapilla, S. borin and S. communis and on Cettia cetti (Cettidae). Strelkoviacarus quadratus, found here only on S. atricapilla, is a polyxenous species known from various passerines and piciformes (Mironov, 1996).

The family Proctophyllodidae is represented by 13 species of 4 genera (one Proctophyllodes species, represented by preimaginal stages only, was identified to the generic level only). Dolichodectes edwardsi, the only representative of the subfamily Pterodectinae in our material, was found on two sylviid hosts, C. cetti and S. melanocephala. It is interesting to note that previously this species was known only from warblers of the genera Acrocephalus Naumann and Phylloscopus Boie (Park and Atyeo, 1971; Mironov, 1996). The other recorded species of this family belong to the subfamily Proctophyllodinae and most of them (10 species) to the genus Proctophyllodes Robin, 1877. Two of the recorded Proctophyllodes species are polyxenous and occur on hosts from different passerine families. Thus, Proctophyllodes clavatus was found on S. borin, S. curruca (Sylviidae) and Locustella luscinioides (Locustellidae), $P$. doleophyes was recorded on S. communis (Sylviidae), 
Gürler A.T. et al.

TABLE 1: Order, family, species and migration status of examined birds.

\begin{tabular}{|c|c|c|c|c|}
\hline Order & Family & Species & Migrating statuses & $\begin{array}{c}\text { Number of infected / } \\
\text { examined birds }\end{array}$ \\
\hline Accipitriformes & Accipitridae & Circus aeruginosus & Partially Migratory & $0 / 1$ \\
\hline \multirow[t]{2}{*}{ Anseriformes } & Anatidae & Mergellus albellus & Migratory & $0 / 1$ \\
\hline & & Netta rufina & Partially Migratory & $1 / 1$ \\
\hline \multirow[t]{4}{*}{ Charadriiformes } & Laridae & Sternula albifrons & Migratory & $0 / 1$ \\
\hline & Scolopacidae & Calidris alpina & Migratory & $0 / 1$ \\
\hline & & Scolopax rusticola & Migratory & $1 / 1$ \\
\hline & & Tringa totanus & Migratory & $1 / 1$ \\
\hline Coraciiformes & Alcedinidae & Alcedo atthis & Partially Migratory & $0 / 3$ \\
\hline Cuculiformes & Cuculidae & Cuculus canorus & Migratory & $0 / 2$ \\
\hline Gruiformes & Rallidae & Porphyrio porphyrio & Resident & $1 / 1$ \\
\hline \multirow[t]{30}{*}{ Passeriformes } & Acrocephalidae & Acrocephalus scirpaceus & Migratory & $1 / 5$ \\
\hline & Aegithalidae & Aegithalos caudatus & Partially Migratory & $0 / 1$ \\
\hline & Cettiidae & Cettia cetti & Resident & $5 / 14$ \\
\hline & Fringillidae & Fringilla coelebs & Partially Migratory & $2 / 4$ \\
\hline & Hirundinidae & Hirundo rustica & Migratory & $1 / 7$ \\
\hline & Motacillidae & Motacilla alba & Partially Migratory & $1 / 2$ \\
\hline & & Motacilla flava & Migratory & $0 / 2$ \\
\hline & Muscicapidae & Erithacus rubecula & Partially Migratory & $6 / 23$ \\
\hline & & Ficedula albicollis & Migratory & $0 / 3$ \\
\hline & & Ficedula hypoleuca & Migratory & $0 / 3$ \\
\hline & & Ficedula parva & Migratory & $0 / 3$ \\
\hline & & Luscinia luscinia & Migratory & $2 / 4$ \\
\hline & & Phoenicurus phoenicurus & Migratory & $1 / 8$ \\
\hline & Laniidae & Lanius collurio & Migratory & $0 / 13$ \\
\hline & Locustellidae & Locustella luscinioides & Migratory & $2 / 2$ \\
\hline & Passeridae & Passer domesticus & Resident & $1 / 3$ \\
\hline & & Passer hispaniolensis & Migratory & $1 / 3$ \\
\hline & Phylloscopidae & Phylloscopus collybita & Partially Migratory & $1 / 6$ \\
\hline & & Phylloscopus trochilus & Migratory & $4 / 9$ \\
\hline & Prunellidae & Prunella modularis & Partially Migratory & $1 / 1$ \\
\hline & Regulidae & Regulus regulus & Migratory & $1 / 1$ \\
\hline & Sturnidae & Sturnus vulgaris & Partially Migratory & $0 / 1$ \\
\hline & Sylviidae & Sylvia atricapilla & Migratory & $19 / 29$ \\
\hline & & Sylvia borin & Migratory & $3 / 8$ \\
\hline & & Sylvia communis & Migratory & $1 / 3$ \\
\hline & & Sylvia curruca & Migratory & $1 / 2$ \\
\hline & & Sylvia melanocephala & Partially Migratory & $4 / 6$ \\
\hline & & Sylvia nisoria & Migratory & $0 / 1$ \\
\hline & Turdidae & Turdus merula & Partially Migratory & $1 / 11$ \\
\hline & & Turdus philomelos & Partially Migratory & $0 / 3$ \\
\hline Podicipediformes & Podicipedidae & Tachybaptus ruficollis & Partially Migratory & $0 / 1$ \\
\hline Strigiformes & Strigidae & Athene noctua & Resident & $0 / 1$ \\
\hline
\end{tabular}


TABLE 2: Family, species, host species and prevalence of identified avian mites.

\begin{tabular}{|c|c|c|c|}
\hline Family & Species & $\begin{array}{l}\text { Host species } \\
\text { (infected/examined individuals) }\end{array}$ & Prevalence $(\%)^{*}$ \\
\hline Alloptidae & Alloptoides aythinae & Netta rufina $(1 / 1)$ & - \\
\hline \multirow[t]{7}{*}{ Analgidae } & Analges passerinus & Fringilla coelebs $(1 / 4)$ & - \\
\hline & A. spiniger & Cettia cetti (1/14) & 7.1 \\
\hline & & Sylvia atricapilla $(4 / 29)$ & 13.8 \\
\hline & & Sylvia borin $(2 / 8)$ & 25.0 \\
\hline & & S. communis $(1 / 3)$ & - \\
\hline & A. turdinus & Turdus merula (1/11) & 9.1 \\
\hline & Strelkoviacarus quadratus & Sylvia atricapilla $(4 / 29)$ & 13.8 \\
\hline Avenzoariidae & Avenzoaria totani & Tringa totanus $(1 / 1)$ & - \\
\hline Freyanidae & Freyana nyrocae & Netta rufina (1/1) & - \\
\hline \multirow[t]{20}{*}{ Proctophyllodidae } & Dolichodectes edwardsi & Cettia cetti (3/14) & 21.4 \\
\hline & & Sylvia melanocephala (1/6) & 16.7 \\
\hline & Joubertophyllodes modularis & Prunella modularis (1/1) & - \\
\hline & Monojoubertia microphylla & Fringilla coelebs (1/4) & - \\
\hline & Proctophyllodes cetti & Cettia cetti $(1 / 14)$ & 7.1 \\
\hline & P. clavatus & Locustella luscinioides (1/2) & - \\
\hline & & Sylvia borin $(2 / 8)$ & 25.0 \\
\hline & & S. curruca $(1 / 2)$ & - \\
\hline & P. doleophyes & Phylloscopus collybita (1/6) & 16.7 \\
\hline & & Ph. trochilus (4/9) & 44.4 \\
\hline & & Sylvia communis $(1 / 3)$ & - \\
\hline & P. lusciniae & Luscinia luscinia (2/4) & - \\
\hline & P. mesocaulus & Phoenicurus phoenicurus (1/8) & 12.5 \\
\hline & P. rubeculinus & Erithacus rubecula (6/23) & 28.1 \\
\hline & P. scolopacinus & Scolopax rusticola (1/1) & - \\
\hline & P. sylviae & Sylvia atricapilla $(17 / 29)$ & 58.6 \\
\hline & & S. melanocephala $(1 / 6)$ & 16.7 \\
\hline & P. troncatus & Passer domesticus (1/3) & - \\
\hline & & Pas. hispaniolensis $(1 / 3)$ & - \\
\hline & Proctophyllodes sp. & Cettia cetti $(1 / 14)$ & 7.1 \\
\hline Pterolichidae & Grallolichus minutus & Porphyrio porphyrio (1/1) & - \\
\hline \multirow[t]{2}{*}{ Pteronyssidae } & Pteronyssoides striatus & Fringilla coelebs $(1 / 4)$ & - \\
\hline & Scutulanyssus hirundicola & Hirundo rustica (1/7) & 14.3 \\
\hline Psoroptoididae & Temnalges mesalgoides & Porphyrio porphyrio (1/1) & - \\
\hline \multirow[t]{7}{*}{ Trouessartiidae } & Trouessartia inexpectata & S. melanocephala (3/6) & 50.0 \\
\hline & T. jedliczkai & Motacilla alba (1/2) & - \\
\hline & T. kratochvili & Locustella luscinioides (1/2) & - \\
\hline & T. microcaudata & Hirundo rustica $(1 / 7)$ & 14.3 \\
\hline & T. reguli & Regulus regulus (1/1) & - \\
\hline & T. rubecula & Erithacus rubecula (4/23) & 17.4 \\
\hline & T. trouessarti & Acrocephalus scirpaceus (1/5) & 20.0 \\
\hline
\end{tabular}

* Calculated only for cases where more than 5 host individuals were examined. 
Phylloscopus collybita, and Ph. trochilus (Phylloscopidae). Other recorded species of the genus Proctophyllodes are known as monoxenous or restricted to birds of one or several related genera of one family (Atyeo and Braasch, 1966). Monojoubertia microphylla is known as a monoxenous inhabitant of the chaffinch Fringilla coelebs. Joubertophyllodes modularis occurs on various Emberiza species (Emberizidae), but also inhabits Prunella modularis, the only host from the family Prunellidae (Atyeo and Gaud, 1971).

The family Pteronyssidae is represented by two species, Pteronyssoides striatus and Scutulanyssus hirundicola. Both species are known as monoxenous parasites of corresponding hosts (Mironov, 1985, 1989).

The family Trouessartiidae is represented by 7 species of the genus Trouessartia Canestrini, 1899. Among these species, Trouessartia kratochvili and T. trouessarti are known from birds of the genera Locustella Kaup and Acrocephalus, respectively; other recorded Trouessartia species are known as monoxenous parasites of their hosts (Santana, 1976).

In relation to the prevalence of recorded feather mite species, it is quite interesting to note that this index in most mite species from passerines is relatively low and does not exceed $50 \%$ (Table 2). For instance, the prevalence of feather mites on many passerine birds in Western Europe was over $60 \%$ (Behnke et al., 1995). Only two mite species in our material show a relatively high prevalence, Proctophyllodes sylviae on S. atricapilla and Trouessartia inexpectata on S. melanocephala, $58.6 \%$ and $50 \%$, respectively. This low prevalence of examined mite species in the present study could be caused by various reasons. For example, almost all passerine birds are migrants (Table 1) and have been examined mainly in the period of migration when they undergo long-lasting and intensive flight activity. Under these conditions, mite populations could decrease or be eliminated. The differences between studies could also reflect the peculiarities of Western and Eastern European passerine populations. To resolve these questions, a more extensive and long-term study of feather mite prevalence in Turkey and neighboring countries is required.

\section{ACKNOWLEDGEMENTS}

We are grateful to all ringers at the Cernek Ringing Station in the Kizilirmak delta for their help in capturing of birds and collecting feather mites. The study was financially supported by the Ondokuz Mayıs University Project Management Office (Project number F-478).

\section{REFERENCES}

Aksın N. 2007 - Freyana anatina (Koch, 1844) feather mites (Acarina, Freyanoidea) recorded for the first time on wild ducks (Subfamily, Anatinae) in Turkey - Acta Parasitol. Turc. 31: 302-305.

Aksin N. 2010 - Chewing lice and feather mites on wild partridges — Ind. Vet. J., 87: 940-941.

Aksin N. 2011 - Feather mites (Acari: Astigmata) on wild quail (Coturnix coturnix) — Ind. Vet. J., 88: 6970 .

Aksın N., Erdoğmuş Z. 2005 - Pseudolichus solutocurtus Dubinin, 1956 (Acarina, Pterolichoidea) and Harpirhynchus sp. (Acarina, Harpirhynchidae Dubinin, 1957) species recorded for the first time on wild partridges in Turkey - T. J. Vet. Anim. Sci., 29: 114956.

Atyeo W.T., Braasch N.L. 1966 - The feather mite genus Proctophyllodes (Sarcoptiformes: Proctophyllodidae) — Bull. Univ. Nebraska State Museum, 5: 1-354.

Atyeo W.T., Gaud J. 1971 - A new genus of feather mites near Proctophyllodes Robin, 1877 (Analgoidea: Proctophyllodidae) - J. Georgia Ento. Soc., 6: 43-50.

Barıș S., Sağlam Ö., Erciyas K., Yavuz N., Özsemir A.C. 2010 - An important natural heritage: Kızılırmak Delta birds. Samsun: Erol Ofset. pp. 169.

Behnke J.M., McGregor P.K., Shepherd M., Wiles R., Barnard C., Gilbert F.S., Hurst J.L. 1995 — Identity, prevalence and intensity of infestation with wing feather mites on birds (Passeriformes) from the Setubal Peninsula of Portugal - Exper. App. Acarol., 19:443-458.

Dabert J., Mironov S.V. 1999 - Origin and evolution of feather mites (Astigmata) - Exper. App. Acarol., 23:437-454. doi:10.1023/A:1006180705101

Evans G.O. 1992 - Principles of acarology. Wallingford: CAB International. pp. 576.

Gaud J., Atyeo W.T. 1996 - Feather mites of the World (Acarina, Astigmata): the supraspecific taxa. Musée Royal del'Afrique Centrale, Ann., Sci. Zool., 277: 1193 (Pt. 1, text), 1-436 (Pt. 2, illustrations). 
Gill F., Donsker D. (Eds). 2012 — IOC World Bird List (v 3.1) Consult www.worldbirdnames.org [Accessed 03.08.2012]

Mironov S.V. 1985 - Feather mites of the genera Analges and Pteronyssoides from the European part of the USSR (Sarcoptiformes, Analgoidea) - Parazitol. Sbornik, 33: 159-208. (In Russian, English summary)

Mironov S.V. 1989 - A review of the feather mites of the subfamily Pteronyssinae from the USSR (Analgoidea, Avenzoariidae) - Parazitol. Sbornik, 35: 96-124. (In Russian, English summary)

Mironov S.V. 1996 - Feather mites of the passerines of the North-West of Russia - Parazitologiya, 30: 521539. (In Russian, English summary)

Mironov S.V. 1997 - Contribution to the feather mites of Switzerland with descriptions of five new species (Acarina: Sarcoptiformes) - Bull. Soc. Entomol., 70: 455-471.

Mironov S.V., Proctor H.C. 2008 - The probable association of feather mites of the genus Ingrassia (Analgoidea: Xolalgidae) with the blue penguin Eudyptula minor (Aves: Sphenisciformes) in Australia - J. Parasitol., 94: 1243-1248. doi:10.1645/GE-1579.1

Mironov S.V., Literak I., Nguen M.H., Capek M. 2012 - New feather mites of the subfamily Pterodectinae (Acari: Proctophyllodidae) from passerines and woodpeckers (Aves: Passeriformes and Piciformes) in Vietnam - Zootaxa (in press).
OConnor B.M. 2009 - Cohort Astigmatina - In: Krantz G.W., Walter D.E. (Eds.). A Manual of Acarology. Lubbock: Texas Tech. University Press. p. 565-657.

Park C.K., Atyeo W.T. 1971 - A generic revision of the Pterodectinae, a new subfamily of feather mites (Sarcoptiformes: Analgoidea) - Bull. Univ. Nebraska State Museum, 9: 39-88.

Peterson P.C., Atyeo W.T., Moss W.W. 1980 - The Feather Mite Family Eustathiidae (Acarina: Sarcoptiformes). Monographs, Academy of Natural Sciences of Philadelphia, 21: 1-143.

Proctor H.C. 2003 - Feather mites (Acari: Astigmata): ecology, behavior, and evolution Annu. Rev. Entomol., 48: 185-209. doi:10.1146/annurev.ento.48.091801.112725

Proctor H.C., Owens I. 2000 - Mites and birds: diversity, parasitism and coevolution - TREE, 15: 358-364.

Santana F.J. 1976 - A review of the genus Trouessartia (Analgoidea: Alloptidae) - J. Med. Entomol., 1: 1128.

\section{COPYRIGHT}

(co) EY-No-ND Gürler A.T. et al. Acarologia is under free license. This open-access article is distributed under the terms of the Creative Commons-BY-NC-ND which permits unrestricted non-commercial use, distribution, and reproduction in any medium, provided the original author and source are credited. 